\title{
Współczesny rynek dystrybucji kinowej w Polsce
}

\author{
AlEKSANDRA BARTOSIEWICZ \\ AGNIESZKA ORANKIEWICZ
}

Podejmując analizę rynku filmowego, należy przyjąć, że proces tworzenia dzieła filmowego nie kończy się na wykonaniu kopii wzorcowej, która de facto finalizuje pracę na planie i w postprodukcji. Następująca po produkcji faza dystrybucji jest nie mniej ważna dla końcowego efektu dzieła, a także dla rozwoju całej branży filmowej. Dystrybucja jest etapem pośrednim, który łączy tzw. produkcję właściwą z odbiorcą dzieła, czyli widzem. Z pewnością jest też procesem kreatywnym, od którego w dużej mierze zależy, czy film odniesie sukces frekwencyjny i finansowy. Przez dystrybucję rozumiemy wszelkie decyzje oraz czynności związane z udostępnieniem wytworzonych produktów kinematograficznych w celu ich publicznego wyświetlenia w miejscach o odpowiedniej infrastrukturze ${ }^{1}$, a także powielanie filmów i ich wtórną dystrybucję (wideo, DVD, telewizja, Internet itp.). Z kolei w polskiej ustawie o kinematografii, ustanawiającej ramy funkcjonowania rodzimego przemysłu filmowego, dystrybucja filmowa jest zdefiniowana bardzo wąsko, jako nabycie prawa do eksploatacji filmu, w tym prawa do wykonywania kopii filmu i przystosowania filmu do eksploatacji w wersji językowej innej niż ta, w której zostal wytworzony, oraz przekazanie tego prawa innym podmiotom w celu rozpowszechniania filmu ${ }^{2}$. Wydaje się jednak, że takie ujęcie dystrybucji nie uwzględnia wyzwań i zadań, jakie przed nią stoją. Nie można bowiem sprowadzać jej do roli jedynie instrumentu pośredniczącego, gdyż pozostaje ona sferą wyraźnie oddziałującą na inne czę́si systemu i współkształtującą ich charakter. Dystrybutorzy ściśle współpracują z producentami - a realia dystrybucji wpływają na strategie producenckie, zależne przecież od dostępu do audytoriów, a więc również od rozpoznania widowni oraz jej preferencji ${ }^{3}$. Tak wąskie pojmowanie dystrybucji w ustawie z 2005 r. jest być może pokłosiem statusu dystrybucji w PRL i takiego o niej myślenia.

Jeśli przyjmiemy, w dużym uproszczeniu, że dystrybucja polega na wprowadzaniu filmów na rynek i utrzymywaniu ich na nim, możemy uznać, iż po wyprodukowaniu film jest po prostu przekazywany do kin, które często stanowią pierwszy kanał dystrybucji i udostępniają go publiczności. W rzeczywistości jednak od decyzji dystrybutora zależy budżet oraz strategia promocji, jak również organizacji pokazów, w tym ustalenie liczby i lokalizacji kin, w których film będzie wyświetlany. Wybiera on także datę premiery kinowej filmu, rozpoznając okresy wysokiego popytu i starając się unikać terminów, w których w kinach pojawią się podobne pozycje ${ }^{4}$. 
Jak się jednak okazuje, tak niezwykle istotny sektor polskiej branży filmowej wciąż jest bardzo słabo rozpoznany przez badaczy. Z wyjątkiem jednego opracowania zbiorowego ${ }^{5}$ brak właściwie jakichkolwiek prac przedstawiających sytuację na rodzimym rynku dystrybucji kinowej. Głównym zamierzeniem niniejszego artykułu jest zatem dodanie nowego głosu w dyskusji przez opisanie etapów powstawania i stabilizowania się tego rynku w Polsce. Ponadto celem pracy jest przedstawienie dowodów empirycznych na polaryzację i zróżnicowanie rynku dystrybucji w Polsce oraz wykazanie wpływu dużych amerykańskich firm dystrybucyjnych na kształt lokalnego przemysłu filmowego.

\section{Rys historyczny}

Rozpoczynając dyskusję o dystrybucji filmowej w Polsce, warto przytoczyć kilka ważnych faktów mających wpływ na powstawanie tego rynku i jego obecny kształt. Po pierwsze, trzeba wspomnieć, że przed rokiem 1989 rynek dystrybucji filmowej w Polsce w zasadzie nie istniał. Podobnie jak wiele innych dziedzin gospodarki, także produkcja i dystrybucja były planowane i zarządzane centralnie. Do 1987 r. prawo do dystrybuowania filmów w Polsce miała Centrala Dystrybucji Filmów (CDF) podlegająca Naczelnemu Zarządowi Kinematografii. Gdy w 1987 r. powołano Komitet Kinematografii, formalnie odebrano CDF pozycję monopolistyczną; co więcej, w latach 1988-1989 kilka filmów amerykańskich wprowadziła na ekrany spółka Film Polski. Po likwidacji CDF dystrybucją filmów zajmowało się kilka regionalnych (choć nadal państwowych) instytucji, dawnych Okręgowych Instytucji Rozpowszechniania Filmów.

Wraz z transformacją systemu społeczno-gospodarczego przekształceniu uległa też sytuacja na rynku dystrybucji filmowej. W 1990 r. miejsce dawnej Centrali Rozpowszechniania Filmów zaczęły zajmować podmioty prywatne. Na rynku pojawiły się dwie dominujące firmy dystrybucyjne, Syrena Entertainment oraz ITI, które swoją przewagę zawdzięczały kontraktom z takimi zagranicznymi firmami produkcyjnymi, jak Columbia, Orion, $20^{\text {th }}$ Century Fox czy Warner. Początek lat 90. dawał polskiemu przemysłowi kinematograficznemu powiew wolności i wydawać by się mogło, że dostęp do szerszego repertuaru kinowego powinien skutkować wzrostem popytu na usługi kinowe. Był to jednak czas ciągłych przemian, inflacji, kaset VHS, co w konsekwencji przełożyło się na niską frekwencję kinową. Szeroko o rynku kaset VHS w tamtym okresie pisze Grzegorz Fortuna Jr. ${ }^{6}$, warto jednak wspomnieć, że był to obszar bardzo dynamiczny i nieuregulowany prawnie. Pomimo niskiej jakości oferowanych produktów dla wielu stanowił szansę na znacznie tańszy dostęp do „,nowości”, a tym samym stał się konkurencją dla pokazów kinowych.

Następnym etapem było pojawienie się na polskim rynku multipleksów, które w latach 1990-2000 zmieniły sytuację w branży dystrybucji filmowej oraz nastawienie widzów do czasu spędzanego w kinie ${ }^{7}$. Multipleksy, jako znaczący gracze na rynku, oraz dostępność filmów zagranicznych (głównie ze Stanów Zjednoczonych) odwróciły także zależność pomiędzy kinem a dystrybutorem. Dotychczas to kino starało się o najlepsze tytuły, teraz natomiast to dystrybutor musiał zabiegać o projekcje swoich tytułów i zwiastunów. Na taki stan rzeczy ogromny wpływ miał także postęp technologiczny i cyfryzacja. Spadek kosztów wytworzenia kopii wzor- 
cowej oraz większa dostępność filmów postawiły kina na lepszej pozycji negocjacyjnej. Jednakże kina nie mają nieograniczonego wpływu na ofertę repertuarową. Mogą co prawda nie wyświetlać danej produkcji, ale nie od nich zależy, jakie tytuły znajdują się w danej chwili w dystrybucji ${ }^{8}$.

Dzisiaj dystrybutor kinowy ponosi też znaczne ryzyko finansowe, które wiąże się głównie z koniecznością wyłożenia kapitału na akcję promocyjną i przygotowanie filmu do wyświetlania oraz z nieprzewidywalnością sukcesu konkretnego tytułu ${ }^{9}$. Warto zauważyć, że dystrybucja w Polsce w zasadzie nie jest objęta wsparciem z publicznych dotacji i subsydiów, w odróżnieniu od bardzo hojnie dotowanego - zwyczajem europejskim - sektora produkcji. Niepewność w przemyśle filmowym sprowadza się do tego, że producent nie może wiedzieć, jaki będzie efekt finalny jego pracy, co chce zrealizować, a konsument, co chce obejrzeć. W literaturze przedmiotu wskazuje się kluczową cechę branży, jaką jest wysokie ryzyko inwestycji w sektorze, w którym niewielka część trafień płaci za niewspółmiernie większą liczbę porażek. To z kolei sprzyja rozwojowi dużych korporacji, które mogą korzystać z ekonomii skali ${ }^{10}$.

\section{Rynek dystrybucji kinowej w Polsce w latach 2002-2018 ${ }^{11}$}

W latach 2002-2018 wprowadzono do polskich kin ponad 3500 filmów, dla których wielkość wpływów ze sprzedaży ponad 569 mln biletów kinowych wyniosła około 10,4 mld zł. W badanym okresie polski rynek dystrybucji kinowej był średnio stabilny, pojawiało się wielu nowych graczy, znikali starzy. Ponad połowa ze 115 analizowanych w badaniu dystrybutorów działała w branży tylko przez rok, a kolejnych jedenastu - przez zaledwie dwa lata. Przez cały analizowany okres dystrybucją kinową w Polsce zajmowało się w sposób ciągły zaledwie siedem firm (Best Film, Gutek Film, Kino Świat, Monolith, Solopan, UIP, Warner). Warto przy tym nadmienić, że ponad jedna czwarta wszystkich objętych badaniem podmiotów współpracowała w analizowanym okresie z innym graczem rynkowym. Przy dość krótkim okresie funkcjonowania firm dystrybucyjnych widoczna jest także tendencja do wchodzenia nowych podmiotów na rynek. W 2018 r. w polskiej branży kinowej rozpoczęło działalność aż siedmiu zupełnie nowych dystrybutorów (Colour Pictures, Film IT, Films For Food, Krkino.pl, Nova Films, Project London, Velvet Spoon).

Przeprowadzone badanie potwierdza, że polska branża dystrybucyjna nie jest homogeniczna, a występujące podmioty możemy podzielić na dwie grupy. Do pierwszej grupy dystrybutorów (tzw. dystrybutorów dużych) można zaliczyć piętnastu największych graczy rynkowych ${ }^{12}$, dla których całkowite wpływy każdego z nich przekroczyły w analizowanym przedziale czasowym $100 \mathrm{mln}$ zł. Do grupy drugiej należy natomiast zaliczyć pozostałych sto firm, których wpływy całkowite w latach 2002-2018 były niższe niż $100 \mathrm{mln}$ zł.

W analizowanym okresie dystrybutorzy duzi byli odpowiedzialni za wprowadzenie ok. 70 proc. wszystkich filmów, które można było obejrzeć w latach 2002-2018 w polskich kinach. Były to przede wszystkim kasowe produkcje hollywoodzkie. Najwięcej tytułów wprowadzili na ekrany tacy dystrybutorzy, jak UIP, Monolith oraz Kino Świat. Uzyskane w badaniu wyniki świadczą o dużym natężeniu konkurencji i średniej koncentracji rynku w grupie dystrybutorów dużych. Liderem na 
rynku dystrybucji kinowej w Polsce pod względem wielkości widowni i wysokości uzyskanych wpływów jest United International Pictures (UIP) ${ }^{13}$, natomiast na drugim miejscu w rankingu znajduje się Kino Świat.

Miarą, która służy do określenia konkurencyjności firm na rynku, jest wskaźnik udziału w rynku. Absolutne udziały rynkowe w ujęciu wartościowym to stosunek przychodów wynikających ze sprzedaży danego przedsiębiorstwa (lub grupy przedsiębiorstw) do przychodów w całej branży. Rynkowe udziały absolutne obu omawianych dystrybutorów wynoszą ponad 36 proc. w ujęciu wartościowym, co oznacza, że firmy te są odpowiedzialne za 36 proc. wszystkich przychodów. W ujęciu ilościowym absolutny udział rynkowy tych firm wyniósł 34 proc., co wskazuje na to, że dystrybuowały one w badanym okresie filmy, które obejrzało ok. 34 proc. widowni zgromadzonej w salach kinowych w latach 2002-2018.

W tym samym czasie dystrybutorzy mali (87 proc. wszystkich dystrybutorów) wprowadzili na ekrany kin ponad tysiąc filmów i jednocześnie tylko jedenastu ${ }^{14}$ z nich dystrybuowało więcej niż czterdzieści produkcji. W analizowanym okresie za największą liczbę filmów odpowiadały Aurora Films (147), Against Gravity (141) oraz Nowe Horyzonty (92). Dla całej grupy małych dystrybutorów absolutne udziały rynkowe wyniosły ok. 5 proc., co oznacza, że zaledwie 5 proc. wszystkich przychodów ze sprzedaży biletów kinowych jest zasługą małych dystrybutorów. Najlepsze wyniki pod względem wielkości wpływów i liczby widzów osiągnęły Mówi Serwis, Syrena (dawne Syrena Films), M2 Films, Hagi Film oraz Aurora Films.

Dla lepszego zobrazowania różnic w strukturze obu opisywanych segmentów, na poniższych wykresach (Wykres 1-2) pokazano wartościowe udziały rynkowe pięciu największych dystrybutorów w każdej z omawianych grup na tle pozostałych konkurentów z branży.

Wykres 1 . Udziały rynkowe pięciu największych dystrybutorów kinowych w polskiej branży filmowej (2002-2018)

Źródło: opracowanie własne

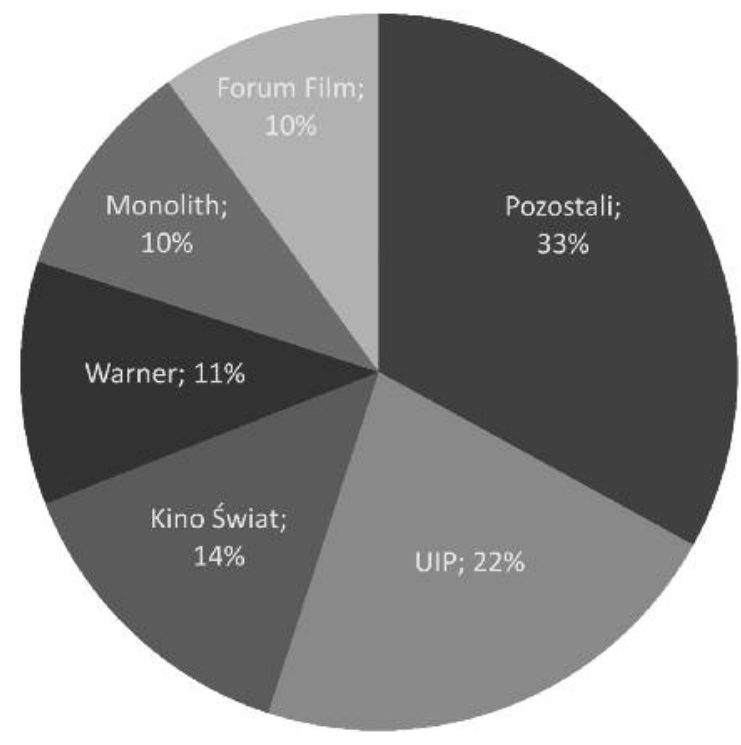


Wykres 2. Udziały rynkowe pięciu najlepszych małych dystrybutorów kinowych w polskiej branży filmowej (2002-2018)

Źródło: opracowanie własne

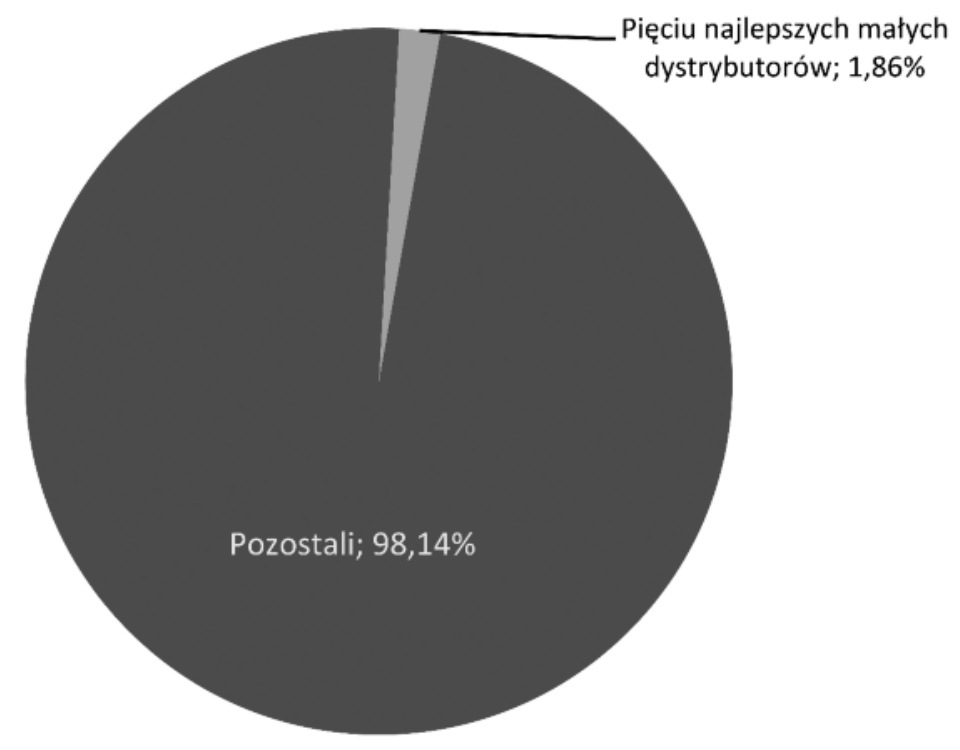

Ponieważ na wysoki box-office wszystkich filmów dystrybutora wpływa zarówno to, jak długo funkcjonuje on na rynku, jak i liczba dystrybuowanych tytułów, warto przyjrzeć się stosunkowi wpływów do liczby pokazywanych filmów. Okazuje się, że w tym przypadku w obu omawianych grupach zwiększa się rola graczy i konsorcjów dystrybutorskich, które w latach 2002-2018 wypromowały zaledwie kilka filmów. I tak w grupie małych dystrybutorów w omawianej kategorii najlepiej wypadają Ent One, Arttech Cinema, Akson oraz Kondrat Media, podczas gdy wśród dużych dystrybutorów są to przede wszystkim konsorcja dystrybutorskie: ITI/Interfilm, Gutek Film/Maxfilm, Gutek Film/Polsat, Kino Świat/SPI, Forum Film/Disney oraz Monolith/SPI. Oznacza to, że dystrybutorzy w Polsce łączą siły przy realizacji pojedynczych i kosztochłonnych projektów w celu osiągnięcia większej widowni. Kooperacja ta jest najczęściej jednorazowa, buduje przewagę konkurencyjną graczy rynkowych i kończy się po wypromowaniu filmu. Jednocześnie pozwala też na łączenie zasobów pozafinansowych (doświadczenie, prawa do filmu), partycypację w kosztach dystrybucji, która umożliwia zebranie większego budżetu na podejmowanie działań marketingowych, jak i ograniczenie ryzyka związanego z projektem dla pojedynczego gracza. Współpraca taka najczęściej okazuje się korzystna dla projektu i skutkuje wysokimi wpływami ze sprzedanych biletów.

Ponieważ struktura rynku może zmienić się w zależności od długości rozpatrywanego okresu, dla porównania warto się przyjrzeć temu, jak się kształtują udziały rynkowe największych dystrybutorów kinowych w Polsce w krótszym czasie. I tak, gdyby wziąć pod uwagę jedynie wyniki z ostatnich pięciu lat (2014- 
2018), okazałoby się, że w rankingu największych udziałowców najlepiej wypada Kino Świat, dla którego wielkość dochodów i widowni jest jednak tylko nieznacznie wyższa od dochodów i widowni wicelidera, UIP. Co więcej, w rankingu tym wyraźniej zarysowuje się silna pozycja Disneya - firmy, która rozpoczęła dystrybucję swoich tytułów w Polsce dopiero w 2012 r. Tak Disney, jak i Kino Świat dobrze wypadają w kategorii relacji wpływów do liczby emitowanych filmów, zajmując odpowiednio drugą i czwartą pozycję w rankingu. $\mathrm{W}$ omawianym zestawieniu najlepiej prezentuje się Interfilm, a tacy dystrybutorzy, jak Warner czy Monolith plasują się w środkowej części stawki, odpowiednio na ósmej i dziesiątej pozycji.

W 2018 r. liczba sprzedanych biletów kinowych w Polsce wyniosła blisko $60 \mathrm{mln}{ }^{15}$. Jednocześnie skoro wiemy, że w 2017 r. przeciętny Polak wydał na zakup biletów do kina około 20,5 zł, a suma wydawana średnio przez Polaków na wizyty $\mathrm{w}$ kinach, teatrach i na koncertach wyniosła w tym roku niecałe 32 zł/os., możemy wnioskować, że w strukturze wydatków gospodarstw domowych na kulturę kino zajmuje pierwszą pozycję ${ }^{16}$. Co więcej, chociaż przeprowadzone analizy wykazały, że dla przeciętnego Polaka wyjście do kina jest z każdym rokiem tańsze ${ }^{17}$, to - jak wynika z badań widowni kinowej finansowanych przez PISF - widzowie wciąż deklarują, że chcieliby ponosić niższe niż obecnie wydatki na kino, a gotowość do płacenia więcej niż obecnie można zauważyć jedynie w grupie widzów kin studyjnych ${ }^{18}$.

Jak się jednak okazuje, tylko nieliczni dystrybutorzy decydują się na oferowanie odbiorcom biletów po cenach wyższych niż przeciętne na rynku. Taką strategię zastosowało w latach 2002-2018 aż sześciu dużych dystrybutorów (UIP, Kino Świat, Monolith, Imperial CinePix, Disney, Next Film) i zaledwie czterech małych (Ent One, Arttech Cinema, Pro Film, Project London). Potwierdza to silną pozycję konkurencyjną tych pierwszych, co może prowadzić do dalszego umacniania ich pozycji na rynku.

Warto wreszcie wspomnieć, że rynek dystrybucji kinowej w Polsce cechuje sezonowość związana ze zwiększoną oglądalnością projekcji kinowych pod koniec oraz na początku roku. Sezonowość w polskim kinie jest w dużej mierze uwarunkowana kulturowo. Niska frekwencja kinowa drugiego kwartału ma związek m.in. z wypadającymi w tym czasie świętami wielkanocnymi. Cechą charakterystyczną dla weekendów przedświątecznych jest małe zainteresowanie kinem ze strony widowni, a tytuły, których premiera przypada na ten czas, nie osiągają dobrych wyników frekwencyjnych. Bardzo często na wynik filmu wpływa też pogoda. Początek wiosny i pierwsze ciepłe dni przypadające na drugi kwartał sprawiają, że ludzie wybierają inne formy spędzania wolnego czasu. Podobnie wygląda trzeci kwartał, na który przypadają wakacje szkolne i czas urlopów. Latem branża unika premier filmowych głównie polskich produkcji, jako że panuje przekonanie, że ich sukces zależy od uczniów i studentów, którzy w tym czasie są na wakacjach ${ }^{19}$. Bardzo korzystny dla kina jest czas w okolicach Bożego Narodzenia i Nowego Roku, natomiast niższe wyniki możemy zaobserwować w dniach przed i po 1 listopada, kiedy przypada Dzień Wszystkich Świętych. 


\section{Wpływ hollywoodzkich gigantów na polską branżę filmową}

W praktyce stosowanej przez Hollywood trzy fazy przemysłu filmowego produkcja, dystrybucja i wyświetlanie - działają najskuteczniej, gdy są zintegrowane wertykalnie. Oddziały głównych studiów hollywoodzkich mają ogólnoświatową sieć dystrybucji dla własnych filmów studyjnych oraz projektów niezależnych producentów i twórców, którzy albo pracują bezpośrednio dla nich w formie podwykonawstwa, albo sprzedają prawa do swoich produkcji ${ }^{20}$. Ponadto istnieje silna integracja głównych wytwórni Hollywood z dystrybucją międzynarodową i ścisła współpraca z sieciami kin na całym świecie ${ }^{21}$. Z integracji pionowej płyną korzyści w postaci ograniczania ryzyka z jednej strony przez zapewnienie popytu na filmy na różnych rynkach, a z drugiej ich ciągłej podaży. Unika się przy tym wysokich kosztów realizacji zamówień przez dostawców zewnętrznych. Ponadto umożliwia to lepszy dostęp do nowych technologii, obniżanie kosztów zakupu i sprzedaży (przez przeciwdziałanie sile przetargowej) czy podniesienie stopy zysku. Integracja pionowa przyczynia się jednak do zwiększania barier wejścia na rynek dla nowych podmiotów, a jej ewidentną wadą jest zwiększanie kosztów stałych przedsiębiorstwa, niska elastyczność strategii rozwojowej oraz duże koszty likwidacji przedsiębiorstwa.

Sukces rynkowy produkcji hollywoodzkich zależy w dużej mierze od pierwszej fazy dystrybucji, tj. dystrybucji kinowej, która ma wpływ na wyniki finansowe także w kolejnych oknach dystrybucji. Dystrybucją hollywoodzkich produkcji zajmują się, najogólniej ujmując, dwie grupy podmiotów ${ }^{22}$ : dominujący na rynku amerykańskim dystrybutorzy duzi oraz tzw. dystrybutorzy niezależni (mali).

Na rynku dystrybucji kinowej w Stanach Zjednoczonych rocznie działa około 150 dystrybutorów ${ }^{23}$, z czego do sześciu największych od kilkudziesięciu już lat niezmiennie zaliczają się: $20^{\text {th }}$ Century Fox (News Corp.), Buena Vista (The Walt Disney Co.), Paramount (Viacom), Sony/Columbia, Universal (NBC Universal), Warner Brothers (WarnerMedia) ${ }^{24}$. Wraz z MGM/United Artists należą oni do amerykańskiego stowarzyszenia Motion Picture Association of America (MPAA), które koncentruje swoje wysiłki przede wszystkim na produkcjach wysokobudżetowych ${ }^{25}$. Co za tym idzie, by móc rozpowszechniać filmy na rynkach krajowych i zagranicznych, podmioty te potrzebują rozbudowanej sieci dystrybucji ${ }^{26}$. Dystrybutorzy duzi rozpowszechniają zazwyczaj własne produkcje na głównych rynkach docelowych, udzielając stosownych licencji innym firmom na rynkach mniej lukratywnych. Aby zabezpieczyć swoje interesy i mieć stały kontakt z menedżerami multipleksów, utrzymują też liczne filie na rynkach zagranicznych.

Okazuje się, że ponad połowa całej dystrybucji kinowej w Polsce jest skupiona w czterech firmach (UIP, Kino Świat, Warner i Monolith), z których dwie (UIP, Warner) to oddziały zagraniczne największych dystrybutorów amerykańskich. Co więcej, liderem na polskim rynku dystrybucji pod względem wielkości wpływów przypadających na jeden film jest polskie biuro Walt Disney Co. (Buena Vista). Potwierdza to, że Hollywood wiedzie prym na globalnym rynku filmowym, ponieważ potrafi wyprodukować najbardziej spektakularne widowiska kinowe, które rozpowszechnia w ramach bardzo dobrze zorganizowanego, hierarchicznie uporządkowanego systemu dystrybucji ${ }^{27}$. Przykładowo, polski oddział Walt Disney 
Co. zajmuje się dystrybucją filmów wytwórni Disneya w polskich kinach, a UIP rozpowszechnia filmy takich wytwórni jak Paramount i Universal oraz MGM/United Artists, nie dystrybuując w ogóle polskich produkcji. Innym przykładem firmy, która wprowadza głównie filmy amerykańskie, jest polskie biuro Warner Bros., które zajmuje się projektami m.in. wytwórni Warner Bros., New Line Cinema czy też Legendary Pictures oraz rodzima firma Forum Film Poland, która prowadziła głównie dystrybucję filmów wytwórni Walta Disneya, Pixar, Universal czy też Touchstone. Natomiast Imperial CinePix oferuje kinom filmy takich wytwórni, jak $20^{\text {th }}$ Century Fox, MGM/United Artists, Paramount i DreamWorks. Nie dystrybuuje filmów polskich i rzadko zajmuje się produkcjami europejskimi. Te znajdują się w kręgu zainteresowań firm rodzimych, takich jak Kino Świat czy Monolith.

W tabeli 1 przedstawiono po trzy najbardziej dochodowe produkcje filmowe pokazywane w Polsce w latach 2002-2018 w podziale na poszczególnych dystrybutorów. Informacje w niej zawarte potwierdzają dotychczasowe wnioski. W analizowanym okresie zlokalizowane w Polsce oddziały dystrybucyjne UIP, Warner i Disney oraz polskie Imperial CinePix i Forum Film w większości przypadków odpowiadały za rozpowszechnianie kasowych produkcji hollywoodzkich, podczas gdy hity rodzimej kinematografii były wprowadzane przez takich dużych dystrybutorów krajowych, jak ITI Cinema, Interfilm i Kino Świat. Jednocześnie wysokobudżetowe produkcje hollywoodzkie stanowią w przedstawionym zestawieniu blisko 63 proc. największych przebojów kinowych w Polsce w latach 2002-2018.

Tabela 1. Dystrybutorzy największych przebojów kasowych na polskim rynku filmowym (2002-2018)

\begin{tabular}{|c|c|c|c|c|c|}
\hline Rok & Film & Dystrybutor & Rok & Film & Dystrybutor \\
\hline \multirow{3}{*}{2002} & WPl: Drużyna pierścienia & Warner & \multirow{3}{*}{2011} & Listy do $M$ & ITI Cinema \\
\hline & HPI: Kamien filozoficzny & Warner & & Och, Karol 2 & Interfilm \\
\hline & Zemsta & Vision & & Piraci z Karaibów 4 & Forum Film \\
\hline \multirow{3}{*}{2003} & WP2: Dwie wieże & Warner & \multirow{3}{*}{2012} & Madagaskar 3 & UIP \\
\hline & Matrix-reaktywacja & Warner & & Skyfall & Forum Film \\
\hline & HP2: Komnata tajemnic & Warner & & Epoka lodowcowa 4 & Imp. CinePix \\
\hline \multirow{3}{*}{2004} & Shrek 2 & UIP & \multirow{3}{*}{2013} & Hobbit 2 & Forum Film \\
\hline & Pasja & Monolith & & Drogówka & Next Film \\
\hline & WP3: Powrót króla & Warner & & Hobbit & Forum Film \\
\hline \multirow{3}{*}{2005} & Karol, czlowiek który... & ITI Cinema & \multirow{3}{*}{2014} & Bogowie & Next Film \\
\hline & HP4: Czara ognia & UIP & & Hobbit 3 & Forum Film \\
\hline & Madagaskar & UIP & & Miasto 44 & Kino Swiat \\
\hline \multirow{3}{*}{2006} & Tylko mnie kochaj & ITI Cin./Interfilm & \multirow{3}{*}{2015} & Listy do M. 2 & Kino Świat \\
\hline & Jan Pawel II & Interfilm & & GW7: Przebudzenie mocy & Disney \\
\hline & Opowieści z Narnii & Forum Film & & Spectre & Forum Film \\
\hline \multirow{3}{*}{2007} & Shrek Trzeci & UIP & \multirow{3}{*}{2016} & Pitbull. Niebezpieczne... & Kino Świat \\
\hline & Katyń & ITI Cinema & & Planeta singli & Kino Świat \\
\hline & Testosteron & ITI Cinema & & Lotr I. GW & Disney \\
\hline \multirow{3}{*}{2008} & Lejdis & ITI Cinema & \multirow{3}{*}{2017} & Listy do M. 3 & Kino Świat \\
\hline & Mamma mia! & UIP & & Botoks & Kino Swiat \\
\hline & Kung Fu Panda & UIP & & $G W:$ Ostatni Jedi & Disney \\
\hline \multirow{3}{*}{2009} & Epoka lodowcowa 3 & Imperial CinePix & \multirow{3}{*}{2018} & Kler & Kino Śswat \\
\hline & Madagaskar 2 & UIP & & Kobiety mafii & Kino Świat \\
\hline & 2012 & UIP & & Nowe oblicze Greya & UIP \\
\hline \multirow{3}{*}{2010} & Avatar & Imperial CinePix & & & \\
\hline & Shrek forever & UIP & & & \\
\hline & Alicja w krainie czarów & Forum Film & & & \\
\hline
\end{tabular}

Źródło: opracowanie własne. 


\section{Podsumowanie}

W prezentowanym artykule przybliżono pokrótce etapy powstawania i stabilizowania się rynku dystrybucji w Polsce, a dzięki przeprowadzonemu badaniu przedstawiono również dowody na polaryzację tego rynku, który pozostaje także pod silnym wpływem dużych amerykańskich firm dystrybucyjnych.

Dystrybucja filmowa w Polsce jest rynkiem dynamicznie rozwijającym się. Z roku na rok rośnie też liczba widowni, a kino staje się bardziej dostępne dla widza. Podobnie jak rynek amerykański, polska branża dystrybucyjna nie jest jednak homogeniczna ${ }^{28}$. Przeprowadzone badania potwierdziły, że rynek dystrybucji filmowej w Polsce jest silnie rozwarstwiony, na co wskazuje przedstawiona identyfikacja dwóch grup dystrybutorów. Pierwszy segment stanowią tzw. dystrybutorzy duzi, tj. 15 firm dystrybucyjnych, które koncentrują aż 95 proc. udziałów rynkowych i są odpowiedzialne za blisko 70 proc. wszystkich filmów, które można było obejrzeć w latach 2002-2018 w polskich kinach. Co więcej, okazuje się, że czterech największych graczy realizuje w Polsce ok. 56 proc. dystrybucji kinowej, jeśli weźmiemy pod uwagę wielkość wpływów (UIP, Kino Świat, Warner, Monolith) i 41,7 proc., gdy uwzględnimy wielkość wpływów przypadającą na jeden film (Disney, ITI Cinema/Interfilm, Mówi Serwis, Interfilm). Potwierdza to wnioski innych badaczy, że na całym świecie na rynkach dystrybucji filmowej można zaobserwować tendencję do formowania się struktur oligopolistycznych ${ }^{29}$. Silna pozycja konkurencyjna na rynku skłoniła ponadto aż sześciu dużych dystrybutorów (UIP, Kino Świat, Monolith, Imperial CinePix, Disney, Next Film) do oferowania widzom biletów kinowych po cenach wyższych niż przeciętne na rynku.

Druga część rynku dystrybucji kinowej w Polsce obejmuje pozostałych stu graczy, którzy pod względem wielkości przychodu odpowiadają za niespełna 5 proc. całego rynku. Segment ten jest jednak bardzo ważny dla rozwoju polskiej kinematografii. Podobnie jak w Stanach Zjednoczonych grupa małych dystrybutorów w Polsce ma też ogromne znaczenie dla kina niszowego, trudnego czy ambitnego. Dzięki temu ich oferta jest dużo bardziej różnorodna i znajduje miejsce dla filmów autorskich, familijnych czy dokumentów, które dla dużych dystrybutorów nie są wystarczająco rentowne. Należy jednak pamiętać, że hity polskiej kinematografii są mimo wszystko wciąż rozpowszechniane przez takich dużych dystrybutorów krajowych, jak ITI Cinema, Interfilm czy też Kino Świat. Mali dystrybutorzy często angażują się natomiast w organizację lub sami są organizatorami różnych festiwali i innych wydarzeń filmowych, promując w ten sposób nie tylko filmy, ale i szeroko rozumianą edukację filmową. Występują w roli koproducentów a także zajmują się pozakinowymi (nieomawianymi w niniejszym artykule) kanałami dystrybucji. Ich różnorodne pola aktywności pozwalają zarówno na zdobycie środków finansowych na działalność stricte dystrybucyjną, jak i na utrzymanie się na rynku.

Ta część rynku jest dużo bardziej rozproszona - czterej najwięksi gracze realizują tu zaledwie 1,86 proc. wpływów całej grupy. Oznacza to małe bariery wejścia na rynek. Większość podmiotów (64 proc. grupy) w całym badanym okresie zajmowała się dystrybucją zaledwie jednego bądź dwóch filmów, co może świadczyć o tym, że małym firmom trudno utrzymać się na rynku. Największym dys- 
trybutorem w grupie jest Aurora Films, zajmująca się rozpowszechnianiem filmów fabularnych dla Sieci Kin Studyjnych i Lokalnych popularyzującej kino o wysokich walorach artystycznych. Innym ważnym dla tego sektora podmiotem jest Against Gravity, które okazjonalnie angażuje się w koprodukcję krajowych produkcji dokumentalnych. Jest to jednak przede wszystkim dystrybutor ambitnych filmów fabularnych i dokumentalnych z całego świata oraz organizator jednego z najważniejszych na świecie przeglądów kina dokumentalnego, Millenium Docs Against Gravity Film Festival. Trzecim pod względem liczby dystrybuowanych filmów jest w omawianej grupie Stowarzyszenie Nowe Horyzonty. Angażuje się ono głównie w kino europejskie oraz jest twórcą i organizatorem Międzynarodowego Festiwalu Filmowego Nowe Horyzonty - miejsca służącego prezentacji odważnego kina artystycznego, które szuka nowych form wyrazu i wykracza daleko poza granice konwencjonalnego filmu. Wart wspomnienia jest również osiągający największe wpływy w grupie Mówi Serwis - firma, która oprócz dystrybucji filmów zagranicznych włącza się w proces produkcji i dystrybucji polskich produkcji. Kolejnym znaczącym graczem na krajowym rynku małych dystrybutorów kinowych jest Syrena (dawne Syrena Films), spółka, która nie tylko zajmuje się dystrybucją filmów, ale także angażuje się w produkcję i prowadzi development scenariuszowy.

AgnieszKa OrankieWicz, Aleksandra Bartosiewicz

${ }^{1}$ M. Jaciow, J. Gałuszka, R. Wolny, M. Kucia, J. Kaczmarzyk, P. Dąbrowski, Z. Kędzior, $R y$ nek audiowizualny w Polsce - diagnoza i perspektywy rozwoju (dla subrynku kinematografii), Fundacja Edukacja Bez Granic, Katowice 2011, s. 19; B. Majewska, Analiza interesariuszy polskiego rynku filmowego, ,Zeszyty Naukowe Politechniki Częstochowskiej. Zarządzanie" 2017, nr 25, s. 143.

2 Tekst ustawy: http://prawo.sejm.gov.pl/isap.nsf/download.xsp/WDU200513211 11/U/D20051111Lj.pdf (dostęp 20.12.2019).

${ }^{3}$ M. Adamczak, K. Klejsa, Badania dystrybucji filmowej: pola problemowe, stan wiedzy, perspektywy rozwoju, w: Wokót zagadnień dystrybucji filmowej, red. M. Adamczak, K. Klejsa, Wydawnictwo PWSFTviT, Łódź 2015, s. 11.

${ }^{4}$ A. De Vany, Hollywood Economics. How Extreme Uncertainty Shapes the Film Industry, Routledge, London 2004, s. 12.

${ }^{5}$ Wokół zagadnień dystrybucji filmowej, dz. cyt. ${ }^{6}$ G. Fortuna, Rynek wideo w Polsce, „Images” 2013, t. XIII, nr 22.

${ }^{7}$ Więcej na ten temat zob. K. Kucharski, Kino plus: film i dystrybucja kinowa w Polsce w latach 1990-2000, Oficyna Wydawnicza Kucharski, Toruń 2002.
${ }^{8}$ R. Wolny, Kreowanie wartości dla klientów kin w Polsce, „Handel Wewnętrzny” 2018, nr 375, s. 396.

${ }^{9}$ Ryzyko finansowe dystrybutora filmowego jest tym większe, im większa jest dostępność poszczególnych tytułów w Internecie. Współczesny dystrybutor musi się zatem liczyć z potencjalnymi stratami wynikającymi z dostępu do nielegalnych kopii filmów, jak i inwestować w dystrybucję cyfrową. Więcej na ten temat zob. m.in. Issues in Future Film Distribution, Screen Australia, Sydney 2015.

${ }^{10}$ N. Garnham, From cultural to creative industries. An analysis of the implications of the „,creative industries" approach to arts and media policy making in the United Kingdom, „International Journal of Cultural Policy” 2005, t. 11, nr 1, s. 19.

${ }^{11}$ Część ta przedstawia pokrótce najważniejsze rezultaty uzyskane przez autorki tekstu z badań rynku dystrybucji kinowej w Polsce w latach 2002-2018. Zakres badania jest determinowany dostępnością danych w bazie boxoffice.pl. Przed 2002 r. nie prowadzono w Polsce żadnych oficjalnych statystyk związanych z dystrybucją filmową, natomiast 2018 r. to ostatnie dane pełnoroczne. 


\section{ALEKSANDRA BARTOSIEWICZ, AGNIESZKA ORANKIEWICZ}

${ }^{12}$ Do największych dystrybutorów w Polsce w analizowanym okresie zaliczają się: UIP, Kino Świat, Warner, Monolith, Forum Film, Imperial CinePix (które powstało 1 lutego 2007 r. w wyniku fuzji Imperial Entertainment z CinePix), Disney, ITI Cinema (dawne Vue Movie), Next Film, SPI, Interfilm, CinePix, Best Film, Vision, Gutek Film.

${ }^{13}$ UIP to joint venture Paramount i Universalu. Spółka zajmuje się dystrybucją kinową na rynkach zagranicznych (tj. poza Stanami Zjednoczonymi i Kanadą).

${ }^{14}$ Są to Aurora Films, Against Gravity, Nowe Horyzonty, Art. House, M2 Films, Hagi Film, Bomba Film, Mayfly, AP Manana, Spectator, Tongariro.

${ }^{15}$ Należy zatem zrewidować stwierdzenie Arkadiusza Lewickiego z 2015 r., że wyniki $\mathrm{z}$ ostatnich lat wykazują, iż widownia $w$ Polsce ustabilizowała się na podobnym poziomie, około 38-39 milionów widzów rocznie. A. Lewicki, Ilu widzów oglądało ,, bergmany”? Dystrybucja $i$ widownia filmowa w Polsce wczoraj i dziś - mity i fakty, w: Wokót zagadnień dystrybucji filmowej dz. cyt. Zob. też: D. Lewandowski, Podsumowanie 2018 roku w polskich kinach, http://boxoffice-bozg.pl/podsumowanie-2018-roku-w-polskich-kinach/ (dostęp: 14.12.2019).

${ }^{16}$ GUS, Kultura w 2017 roku, Główny Urząd Statystyczny, Warszawa 2018, s. 94.

${ }^{17} \mathrm{~W}$ badanym okresie rosła co prawda średnia cena biletu do kina, ale towarzyszył jej szybszy wzrost płacy minimalnej.

${ }^{18}$ Z. Cieślak, M. Jaworowski, Widz kinowy w Polsce. Raport z badania przeprowadzonego dla Filmweb Sp. z o.o., Polski Instytut Sztuki Filmowej, Warszawa 2018.

${ }^{19}$ Por. debatę Specyfika filmowego rynku dystrybucyjnego w Polsce z 27 kwietnia 2016 r. w Tarnowskim Centrum Kultury. Rynek dystrybucji zmienia się https://www.sfp.org.pl/wydarzenia,5,23109,1,1,-.html (dostęp: 15.12.2019).

${ }^{20}$ A. J. Scott, A New Map of Hollywood: The Production and Distribution of American Motion Pictures, ,Regional Studies” 2002, t. 36, s. 969.

${ }^{21}$ A. Muñoz Larroa, N. Ferrer-Roca, Film Distribution in New Zealand: Industrial Organization, Power Relations and Market Failure, „Media Industries” 2017, t. 4, nr 2, s. 3.

${ }^{22}$ Podział ten z każdym rokiem coraz bardziej się zaciera. Nie jest on jednak tutaj głównym przedmiotem zainteresowania. Warto jedynie zauważyć, że wśród dystrybutorów kina hollywoodzkiego w ramach odrębnej grupy wymieniane są też czasami podmioty-córki dużych dystrybutorów lub dystrybutorzy średniej wielkości (tzw. mini-majors), do których są zaliczane Metro-Goldwyn-Mayer (MGM), New Line Cinema, Lion's Gate i Miramax. A. J. Scott, Hollywood and the World: The Geography of Motion-Picture Distribution and Marketing, ,Review of International Political Economy" 2004, t. 11, s. 33; J. Eliashberg, A. Elberse, M.M. Leenders, The Motion Picture Industry: Critical Issues in Practice, Current Research, and New Research Directions, „Marketing Science” 2006, t. 25, nr 6, s. 647.

${ }^{23}$ Dystrybutor jest tu rozumiany jako pośrednik, który kupuje film od producenta i udostępnia go kinom na zasadzie licencji. J. D. Silver, Hollywood's dominance of the movie industry: How did it arise and how has it been maintained?, Queensland University of Technology, Queensland 2017, s. 175.

${ }^{24} \mathrm{~W}$ niektórych opracowaniach mówi się nie o ,wielkiej szóstce” amerykańskich dystrybutorów kinowych, ale o ośmiu największych dystrybutorach. Do grupy tej dodaje się wówczas MGM/United Artists (oficjalnie przejęte w 2005 r. przez Sony) oraz DreamWorks SKG (zakupione w 2006 r. przez Paramount). P. Drake, Distribution and Marketing in Contemporary Hollywood, w: The Contemporary Hollywood Film Industry, red. P. McDonald, J. Wasko, Wiley-Blackwell, Hoboken 2008, s. 65; A. Finney, E. Triana, The International Film Business. A market guide beyond Hollywood, Routlegde, London-New York 2015, s. 8.

${ }^{25}$ Por. https://www.motionpictures.org/who-weare/ (dostęp: 1.03.2019).

${ }^{26}$ A. J. Scott, Hollywood and... dz. cyt., s. 34.

${ }^{27}$ K. Jajko, Hollywood atakuje! W jaki sposób wielkie wytwórnie radza sobie z wyzwaniami stawianymi przez Internet, w: Wokól zagadnień dystrybucji filmowej, dz. cyt., s. 87.

${ }^{28} \mathrm{M}$. Adamczak, W cieniu bomby. O dystrybucji filmowej, https://www.dwutygodnik.com/artykul/7334-w-cieniu-bomby-o-dystrybucjifilmowej.html?print=1 (dostęp: 9.04.2019).

${ }^{29}$ A. Muñoz Larroa, N. Ferrer-Roca, dz. cyt., s. 3. 